\title{
SUPERFUND TAXES AND EXPENDITURES: REGIONAL REDISTRIBUTIONS
}

\author{
Douglas W. McNiel, Andrew W. Foshee, and Clark R. Burbee*
}

\section{Introduction}

The "Hazardous Substance Response Trust Fund," more commonly known as the "Superfund," was authorized under the Comprehensive Environmental Response, Compensation, and Liability Act of 1980 to finance the cleanup of abandoned hazardous waste sites. Despite widespread agreement that the Superfund program should continue, its budgetary authority expired on Sept. 30, 1985. A congressional stalemate over the amount and source(s) of funding for the program lasted until October of 1986 when the Superfund Amendments and Authorization Act was passed (P.L. No. 99-499).

During its first five years, over $\$ 1.1$ billion $(70.8$ percent) of the $\$ 1.6$ billion in total revenues accumulated in the original Superfund came from earmarked excise taxes on petroleum and chemicals. ${ }^{1}$ The earmarked tax revenues, which financed the lion's share of the Superfund over this period, came from an excise tax on petroleum of 0.79 cents per barrel and excise taxes ranging from 22 cents to $\$ 4.87$ per ton on 42 feedstock chemicals (P.L. No. 96510). Over the next five years, the 1986 Superfund legislation provides for collecting $\$ 2.75$ billion from substantially higher taxes on petroleum (8.2 cents per barrel on domestic and 11.7 cents per barrel on imports) and \$1.4 billion from slightly expanded taxes on feedstock chemicals. $^{2}$

The expenditure side of the Superfund program has been analyzed by Barnett (1985). He found that the Environmental Protection Agency has allocated cleanup expenditures to various uncontrolled hazardous waste sites so as to minimize the actual or potential damages to society. Unfortunately, Barnett's analysis focused solely on the expenditure allocation side of the program. The revenue side of the Superfund program has received very little attention (Foshee and McNiel, 1985a, 1985b; Viard, 1985). The principal objective of this paper is to address part of this deficiency by exploring the efficiency and equity aspects of Superfund financing arrangements with particular emphasis on the regional implications of the

*Douglas W. McNiel and Andrew W. Foshee are associate professors in the Department of Economics and Finance at McNeese State University, Lake Charles, La. Clark R. Burbee is an agricultural economist with the Cooperative State Research Service, U.S. Department of Agriculture, Washington, D.C. fund.

\section{Superfund Taxes: Theoretical Considerations}

Statutory liability for the earmarked Superfund excise taxes is levied at the point of first sale or use of the petroleum and chemical feedstocks. ${ }^{3}$ The economic justifications for using these earmarked excise taxes, rather than general revenues, to finance such a major portion of the Superfund program involve at least three interrelated efficiency and equity considerations. First, congressional testimony indicates that support for this financing arrangement was based on the notion that the taxes were considered "fair" in the sense that large amounts of hazardous wastes were believed to be generated as a consequence of the production or use of petroleum and the other taxed feedstock chemicals. Externalities associated with these activities were deemed responsible for the problems at sites requiring Superfund attention. ${ }^{4}$ Second, as a mechanism for linking tax and expenditure decisions, it was argued that the earmarking arrangement induces preference revelation, thereby facilitating a more efficient allocation of resources to Superfund cleanup activities. Finally, the earmarked excise taxes were intended to be useful for regulatory purposes in controlling hazardous waste externalities. Theoretical considerations surrounding each of these arguments are discussed in the remainder of this section. Empirical evidence regarding these arguments is presented in the following section.

The notion that the excise taxes on petroleum and feedstock chemicals are "fair" is the most commonly cited justification for this financing arrangement. However, judged by its own standard of fairness, this tax policy may be seriously flawed if the relationships between feedstock production or use, hazardous waste generation, and disposal externalities are not fixed. If these relationships are flexible, this Superfund financing arrangement will unduly penalize production processes which produce or use large amounts of taxed feedstocks but generate relatively little hazardous waste or, more importantly, result in few disposal externalities. Allocative inefficiencies are likely to result. From an equity viewpoint, those who benefit from production processes which generate more hazardous waste, or those who dispose of hazardous wastes in a more dangerous but less costly manner do not necessarily pay 
more taxes. ${ }^{5}$ Those who generate less waste or who adopt waste management practices that internalize the costs of hazardous waste handling and disposal do not lessen their tax liability, but rather incur additional costs which may lessen their competitiveness.

Whether the linkage between Superfund expenditures and taxes induces preference revelation depends on the extent to which the beneficiaries of cleanup operations necessarily pay the taxes. The federal government's payment of 90 percent of the cleanup costs at a Superfund site may encourage overconsumption, since the local citizenry (who capture most of the benefits from cleanup operations and pay no more than 10 percent of costs) might view Superfund cleanup operations as a "free good" (Cato, 1985). With this financing arrangement, petroleum and chemical feedstock producers or users may be the only group to view the Superfund as "non-free" or costly. If these individuals do not receive benefits from cleanup operations in proportion to their tax liability, they are likely to understate their preferences for Superfund cleanup operations. ${ }^{6}$

Finally, it would appear that the Superfund excise taxes provide incentives for firms to curtail their petroleum and feedstock chemical production or use. But the taxes offer no incentives for voluntary compliance with regulations designed to curtail the generation of hazardous waste or to ensure that it is handled and disposed of in a safe manner. ${ }^{7}$ Achievement of the latter result also depends upon the existence of fixed relationships between petroleum and feedstock chemical production or use, hazardous waste generation, and disposal externalities so that a tax discouraging the first of these activities would curtail the latter two activities as well.

\section{Empirical Evidence: A Regional Test}

Since the 1986 reauthorization legislation more than tripled the amount of Superfund revenue to be collected from earmarked excise taxes on petroleum and feedstock chemicals, it is important to determine the extent to which this financing arrangement is justified by the three arguments presented in the previous section. A direct test of the first of these issues would require an analysis of the extent to which petroleum and feedstock chemical production or use (and, therefore, Superfund tax contributions) by individual firms are related to their generation of hazardous wastes or creation of disposal externalities. Unfortunately, neither the IRS nor the EPA collects or tabulates the necessary data in this form. However, regional data by state was developed to allow an indirect test of the most relevant issues.

The major argument for using earmarked excise taxes on petroleum and feedstock chemicals to finance the Superfund is based upon the premise that there is a strong fixed relationship between petroleum and feedstock chemical production or use and the generation of hazardous waste and disposal externalities. If this premise is correct, then variations in Superfund tax contributions from each state (which are proportional to petroleum and feedstock chemical production or use) should be largely explained by variations in the amount of hazardous waste generated or the number of hazardous waste sites (a proxy for disposal externalities) among the states.

\section{Data}

The EPA has inventoried almost 19,000 uncontrolled hazardous waste sites. To be eligible for long-term remedial measures under the Superfund program, a site must be evaluated on EPA's Hazard Ranking System to determine if it should be included on the National Priorities List. As of October 1984, 538 sites met the criteria for inclusion on the NPL and another 248 sites had been proposed for addition to the NPL. The validity of the underlying justifications for the original Superfund excise taxes can be inferred by using ordinary least squares regression to examine cross section state data on Superfund tax collections (Chemical Manufacturers Association, 1985), the location of hazardous waste sites (U.S. Environmental Protection Agency, October 1984), the generation of hazardous waste (Office of Technology Assessment, 1983), and the allocation of Superfund expenditures (Chemical Manufacturers Association, 1985). ${ }^{8}$

\section{Results}

The relationship between state tax contributions (TAX) and hazardous waste generation (WASTE) is examined in Equation 1 of Table 1. While tax contributions (and, therefore, petroleum and feedstock chemical production or use) are significantly and positively related to hazardous waste generation, it should be noted that the explanatory value of this variable alone is relatively low $\left(\mathbf{R}^{2}\right.$ $=0.17$ ), indicating that most of the variation in state tax contributions to the Superfund is not explained by hazardous waste generation.

The relationship between state tax contributions and hazardous waste sites (a proxy for disposal externalities) is examined in Equations 2 and 3. Variations in Superfund tax contributions from a state are not found to be significantly and positively related to either the number of approved NPL sites in a state (NPLSITES, Equation 2) or the total number of actual and proposed NPL sites in a state (TOTSITES, Equation 3). It is noteworthy that after 
Table 1

Regression Results
1. TAX $=-4,511.80+16.49$ WASTE, $(6,288.73) \quad(5.28)^{*}$
$\mathrm{N}=51, \mathrm{R}^{2}=0.17, \mathrm{~F}(1,49)=9.76$
2. TAX $=8,250.55+37.39$ NPLSITES, $(6,273.37)(351.86)$

$$
\mathrm{N}=51, \mathrm{R}^{2}=0.0002, \mathrm{~F}(1,49)=0.01
$$$$
\mathrm{N}=51, \mathrm{R}^{2}=0.0076, \mathrm{~F}(1,49)=0.37
$$
3. $\mathrm{TAX}=6,128.04+165.27$ TOTSITES, $(6,544.03)(270.32)$
4. TAX $=-2,704.40-1,133.93$ NPLSITES +28.89 WASTE, $(5,922.38) \quad(403.23)^{*}$
$(6.62)^{*}$
$\mathrm{N}=51, \mathrm{R}^{2}=0.28, \mathrm{~F}(2,48)=9.52$
5. TAX $=-2,243.73-1,008.28$ TOTSITES +32.83 WASTE, $(5,939.81) \quad(357.56)^{*}$ (7.61)*

$$
\mathrm{N}=51, \mathrm{R}^{2}=0.28, \mathrm{~F}(2,48)=9.55
$$
$\mathrm{N}=51, \mathrm{R}^{2}=0.01, \mathrm{~F}(1,49)=0.29$
6. $\mathrm{TAX}=7,030.00+0.25$ SFEXPEND, $(5,922.37)(0.46)$
7. $\mathrm{TAX}=-7,734.22+7.42$ VSHIP29. $(3,745.86) * *(0.65)^{*}$
$\mathrm{N}=35, \mathrm{R}^{2}=0.80, \mathrm{~F}(1,33)=131.50$
8. $\mathrm{TAX}=2,222.66+0.59$ PCINCOME,
$\mathrm{N}=51, \mathrm{R}^{2}=0.0007, \mathrm{~F}(1,49)=0.04$
9. TAX $=-14,214.46-1,001.91$ NPLSITES + 30.39 WASTE -0.40 SFEXPEND + 1.07 PCINCOME, $(30,225.78)(475.19)^{* *} \quad(7.09)^{*} \quad(0.61)$ $\mathrm{N}=51, \mathrm{R}^{2}=0.29, \mathrm{~F}(4,46)=4.74$

10. TAX $=-17,553.34-993.93$ TOTSITES + 33.34 WASTE - 0.13 SFEXPEND + 1.44 PCINCOME, $\begin{array}{llll}(30,399.06) & (482.71)^{* *} \quad(7.81)^{*} & (0.69) & (2.82)\end{array}$

TAX = state tax contributions to the Superfund,

NPLSITES = number of uncontrolled hazardous waste sites in the state on the EPA's National Priorities List,

TOTSITES = total number of actual and proposed NPL sites in a state,

WASTE = metric tons of hazardous waste generated in a state,

PCINCOME = state per capita income,

SFEXPEND = Superfund expenditures obligated to a state, and

VSHIP29 = state value of shipments in SIC 29, petroleum refining.

*Coefficient significant at the one percent level

**Coefficint significant at the five percent level

Note: Standard errors are in parentheses.

adjusting for the amount of hazardous waste generated in a state, tax contributions to the Superfund are significantly and negatively related to both the number of NPL sites (Equation 4) and the total number of actual and proposed NPL sites in a state (Equation 5). These results suggest that, with regard to the "fairness" argument, the taxes do not appear to be closely aligned with hazardous waste generation or externalization of disposal costs. Consequently, the taxes are also likely to be of little use for regulatory purposes.

It was argued that the earmarking arrangement might facilitate preference revelation if the taxes were distributed in accordance with the benefits received from cleanup operations. However, no significant positive relationship is found in Equation 6 between a state's tax contributions to the Superfund and its benefits received in the form 
of Superfund expenditures obligated to the state (SFEXPEND). Since the distribution of the Superfund taxes does not appear to be closely aligned with the benefits received from cleanup operations, the earmarking relationship is unlikely to induce preference revelation or facilitate a more efficient allocation of resources.

Obviously, the most important determinant of a state's contributions to the Superfund is the amount of petroleum and chemical feedstocks produced or used in the state. Equation 7 demonstrates that 80 percent of the variation in state tax contributions to the Superfund can be explained by the importance of a single industry, petroleum refining, in the state; VSHIP29 represents the state's value of shipments in Standard Industrial Classification 29 , petroleum refining. This variation, of course, is because the earmarked excise taxes which finance the Superfund are levied on the production or first use of petroleum and petrochemical feedstocks.

Since (1) the Superfund taxes and expenditures do not appear to be closely aligned with the benefits received principle, and (2) certain regions of the country tend to have a comparative advantage and, therefore, specialize in the taxed activities, it is quite possible that the Superfund tax and expenditure program will result in a redistribution of income among regions. This possibility is confirmed by Table 2, which shows Superfund tax collections and ex- penditure obligations per thousand population and the percent of Superfund tax collections, expenditure obiligations, and NPL sites all by census region. Superfund tax collections per thousand population (column one) range from a high of $\$ 13,868$ in the West South Central region, which includes the oil producing and refining states of Louisiana, Oklahoma, and Texas, to a low of only $\$ 23$ in New England, where the taxed activities are of relatively little regional importance. On the other hand, Superfund expenditure obligations per thousand population (column two) range from a low of $\$ 215$ in the East South Central region to a high of $\$ 3,123$ in New England. The figures in column five suggest that these regional disparities are unlikely to narrow in the future unless the method of financing the Superfund is changed, since the East South Central and the West South Central regions (which make the highest per capita tax contributions to the Superfund) also have the smallest percentages of sites on the NPL eligible for future Superfund financing.

Since the Superfund program appears to have substantial regional redistribution effects, it is important to know whether financing of the program is consistent with the other widely accepted criteria of tax equity, namely the ability-to-pay principle. Equation 8 in Table 1 indicates that a state's tax contributions to the Superfund are not significantly and positively related to state per capita in-

Table 2

Superfund Tax Collections, Expenditures, and Sites by Census Region

\begin{tabular}{|c|c|c|c|c|c|}
\hline \multirow{2}{*}{$\begin{array}{l}\text { Census } \\
\text { Region }\end{array}$} & \multirow{2}{*}{$\begin{array}{c}\text { Superfund } \\
\text { Tax Collections } \\
\text { per } 1,000 \\
\text { Population }\end{array}$} & \multirow{2}{*}{$\begin{array}{c}\text { Superfund } \\
\text { Expenditures } \\
\text { per } 1,000 \\
\text { Population }\end{array}$} & \multicolumn{2}{|c|}{ Per Cent Superfund } & \multirow{2}{*}{$\begin{array}{l}\text { Percent } \\
\text { Sites } \\
\text { on NPL }\end{array}$} \\
\hline & & & Collections & Expenditures & \\
\hline New England & 23 & $\$ 3,123$ & 0.1 & 11.6 & 8.6 \\
\hline Mid Atlantic & 474 & 2,822 & 4.0 & 31.1 & 29.1 \\
\hline E. N. Central & 779 & 759 & 7.4 & 9.5 & 22.2 \\
\hline W. N. Central & 291 & 2,853 & 1.1 & 14.7 & 7.2 \\
\hline South Atlantic & 376 & 534 & 3.2 & 5.9 & 12.2 \\
\hline E. S. Central & 1,761 & 215 & 5.9 & 1.0 & 4.0 \\
\hline W.S. Central & 13,868 & 996 & 74.8 & 7.1 & 4.6 \\
\hline Mountain & 372 & 1,534 & 1.0 & 5.2 & 5.5 \\
\hline Pacific & 376 & 1,462 & 2.7 & 13.9 & 6.6 \\
\hline
\end{tabular}


come (PCINCOME). The estimated coefficients in Equations 9 and 10 reaffirm our earlier conclusions that a state's tax contributions to the Superfund are not significantly and positively related to (1) past polluting actions as measured by the number of hazardous waste sites in the state (nor, consequently, the potential benefits that the state may receive from future cleanup expenditures), (2) the benefits received by present residents in the form of Superfund cleanup expenditures obligated to the state, or (3) the state's ability to pay. While state tax contributions are significantly and positively related to the amount of hazardous waste generated in the state, most of the variation in state tax contributions remains unexplained by these four variables $\left(R^{2}=0.29\right)$.

\section{Summary and Conclusions}

Even though Superfund expenditures may be allocated efficiently (Barnett, 1985), these expenditures should not be viewed in isolation from the earmarked tax revenues used to finance them. It has been argued that the excise taxes earmarked to finance the Superfund (1) fail to meet generally accepted efficiency and equity criteria, (2) provide no incentive for voluntary compliance with regulations designed to ensure the safe disposal of hazardous wastes, and (3) when considered in conjunction with the arrangements for allocating cleanup expenditures, are unlikely to induce voters to reveal accurately their preferences for measures to deal with risks posed by uncontrolled hazardous waste disposal sites.

The empirical results indicate the Superfund tax and expenditure provisions result in disproportionate penalties for some regions of the country and disproportionate benefits for other regions. The empirical evidence suggests a number of underlying reasons for the resulting regional disparities. Tax contributions to the Superfund are not directly related to the number of hazardous waste sites in a state, the benefits received by a state in the form of Superfund expenditure obligations, or a state's ability to pay. A more rational financing arrangememt might utilize earmarked revenues which are more consistent with the three criteria enumerated above or general revenues collected in accordance with the ability to pay principle (McNiel and Foshee, 1988).

\section{Notes}

'The balance of the original Superfund receipts came from appropriations from general revenues (10.2 percent), accumulated interest (15.4 percent), transfers from other funds ( 0.4 percent), and receipts from cost recovery actions against companies or individuals found liable for environmental damages associated with hazardous waste disposal (3.2 percent) (U.S. Environmental Protection Agency, December 1984).

${ }^{2}$ Over the succeeding five years, the 1986 reauthorization legislation provides for raising $\$ 8.5$ billion: $\$ 4.15$ billion from the earmarked excise taxes on petroleum and feedstock chemicals, $\$ 2.5$ billion from a new earmarked tax on corporate income, $\$ 1.25$ billion from general treasury revenues, $\$ 300$ million from interest on accumulated funds, and $\$ 300$ million from cost recovery actions against companies responsible for hazardous waste sites (McNiel, Foshee, and Vile, 1987).

${ }^{3}$ Domestically produced petroleum and feedstock chemicals are taxed at the point of first sale. Imported petroleum and chemicals are taxed at the point of first use.

"This argument ignores the intertemporal problems of using revenues generated from taxing present economic actions to pay for remedies to externalities resulting from past economic actions.

'For example, EPA estimates that 84 percent of the waste at the PAS-Oswage Superfund site in New York State was disposed of by companies that made no contribution to the Superfund. These companies employed production processes that did not produce or use petroleum or taxed chemical feedstocks, yet generated sizable waste disposal externalities.

${ }^{6}$ Some evidence of the effect of Superfund revenue and expenditure provisions on preference revelation is provided by the fact that environmental groups cite studies which conclude adequate financing of the Superfund may require as much as $\$ 100$ billion. On the other hand, the Chemical Manufacturers Association and the American Petroleum Institute cite studies which conclude that the EPA could not efficiently spend more than a billion dollars per year over the next five years on Superfund activities and that the scope of the problem is far more limited (in the range of $\$ 9.1$ to $\$ 14.5$ billion).

'The Resource Conservation and Recovery Act of 1976 set forth guidelines for the treatment, storage, transportation, and disposal of hazardous wastes. Externalizing the costs of handling and disposing hazardous waste would not affect a firm's Superfund tax liability; yet, if detected and found in violation of regulations promulgated under RCRA, such actions might result in future financial obligations for the firm.

SSuperfund revenue and expenditures data included fiscal years 1981 through 1985.

\section{References}

Bameth, Harold C. "The Allocation of Superfund, 19811983." Land Economics. 61 (1985). 255-262.

Cato Policy Report. November-December, 1985.

Chemical Manufacturers Association. "Superfund Collections and Disbursements." December 1985.

Foshee, Andrew W., and Douglas W. McNiel. "Superfund Financing: Revenue Predictability Versus Incentives." Atlantic Economic Journal. 13 (1985). 93.

"Economic Impact of Superfund Financing on the Petrochemical Industry." Oil and Gas Tax Quarterly. 34 (1985). 375-385.

McNiel, Douglas W., and Andrew W. Foshee. "Superfund 
Financing Alternatives." Policy Studies Review. 7 (1988). McNiel, Douglas W., Andrew W. Foshee, and John R. Vile.

"New Superfund Legislation: Major Provisions, Revenue Sources, and Economic Incentives for Environmental Protection." Oil and Gas Tax Quarterly. 35 (1987). 610 619.

Office of Technology Assessement. Technologies and Management Strategies for Hazardous Waste Control. Washington, D.C.: Office of Technology Assessment, March 1983.

Public Law Number 96-510, December 11, 1980.
Public Law Number 99-499, October 17, 1986.

U.S. Environmental Protection Agency. Hazardous Substance Response Trust Fund Receipts, Obligations, and Disburse ments: Final Report. Washington, D.C.: U.S. Environmental Protection Agency, December 1984. - National Priorities List: 786 Current and Proposed Sites in Order of Ranking and by State. Washington, D.C.: U.S. Environmental Protection Agency, October 1984.

Viard, Allen D. "Tax Issues Raised By Superfund Reauthorization." Tax Notes. 28 (1985). 1026-1031. 